\title{
The Social Contract Theory and Corporation Moral Obligation
}

\author{
Husein Inusah", Peter Sena Gawu²
}

Abstract: Contractual moralists, such as Bowie and Donaldson, have argued that contractual agreement explains why corporations have a moral obligation towards the society in which they operate. They argue that a corporation's moral obligation emerges from a hypothetical social contract that establishes its legitimacy to operate in society. Their assumption appears to indicate a logically necessary relationship between a corporation's moral obligation and contractual agreement that establishes the corporation. We argue that there is no such relationship: a corporation's moral obligation does not necessarily emerge from a social contract. We suggest that instead of assuming that a corporation's moral obligation emerges from a social contract, it should be said that a corporation's moral obligation is sustained by a social contract. This helps answer the question of why corporations have a moral obligation towards the society where they operate in a better light.

Keywords: Morality; Contractual Agreement; Social Contract; Moral Obligation; Rational Choice; Incorporated Corporations.

\footnotetext{
${ }^{1}$ Department of Classics and Philosophy, University of Cape Coast, Ghana, hinusah@ucc.edu.gh.

2 Department of Classics and Philosophy, University of Cape Coast, Ghana.
} 


\section{INTRODUCTION}

Some prominent defenders of Corporate Social Responsibility (CSR) hinge their idea on contractual morality, according to which there is a contract between corporations and society where corporations are expected to accept moral obligations towards members of the host community (Bowie 1992 and Donaldson 1982). This position appears to extract the moral ingredient in corporate social responsibility from social contract theory. The crux of the thought is that before a corporation is established as a legal entity, it needs to seek permission from the society to do business and the society, in turn, places certain obligations and duties on the corporation. By this, the corporation enters into a relation of obligation between itself and the society and it is morally binding on it to meet these obligations imposed on it by society. In other words, this contract imposes a moral constraint on corporations to meet certain social obligations meant to improve the lives of members of host communities.

On a deeper reflection, the defenders of contractual morality commit a fundamental mistake with regards to the contractual foundation upon which they construct a corporation's moral obligation. It is true that corporate social responsibility has a moral foundation but to extract such moral foundation from a contractual agreement is quite superficial and does not delve deep enough to unravel the source of morality that justifies corporate social responsibility initiatives. The reason is that a contractual agreement between two parties does not necessarily impart morality on the agreement. For instance, the contractual agreement to murder someone is not inherently moral. Thus, morality does not necessarily emerge from contractual agreement between parties on stealing, corruption, defamation and many other social vices. This means that the strategy of constructing corporate social responsibility initiatives on the morality that emerges from social contract appears quite superficial because contractual morality does not necessarily impose a moral obligation on corporations. The implication emerging from our position is that there is no logically necessary relationship between corporation's moral obligation and the contractual agreement that, for want of a better word, causes it. Hence, in an attempt to rebut the claim of the contractual moralist of corporate social responsibility, we argue that a corporation's moral obligation does not necessarily emerge from a social contract that establishes it. We argue further that what contractual agreements do is that they sustain a corporation's moral obligation towards the society: they do not cause it.

\section{SOCIAL CONTRACT THEORY AND CORPORATE MORALITY}

The social contract theory is roughly the view that a person's moral, political or legal obligation is contingent upon a contract or an agreement binding upon her and others to institute regulations or standards on which their society is run. This doctrine may be an old conception rooted in Plato's work, Crito. In Crito, Socrates deploys something quite like a social contract theory to explain to Crito why he must accept the death penalty $(49 \mathrm{e}, \mathrm{ff}) .{ }^{3}$ A more robust conception of the social contract theory is usually credited to Thomas Hobbes who argues that it is natural for human beings to forfeit their liberty and freedom and mutually cede same to others for security and self-preservation under an absolute authority in order to escape the state

\footnotetext{
${ }^{3}$ In the Crito, Socrates appears to suggest that by responding to the obligation to obey the laws of the land, he is keeping to the contractual agreement to abide by the law and accept his punishment. He avers that the city makes laws for the marriage between his parents that led to his birth and outlined the regulations by which he should be raised as a child. These to him are honours the city has done to him and it is contingent upon his agreement to obey the decision the city makes and therefore he cannot fall out of the contract.
} 
of nature (Hobbes 1995). Another influential literature on the subject is Locke's conception of the social contract according to which the quest to protect property in the state of nature is the driving force that propels the establishment of a contract upon which the society constructs a civil government. ${ }^{4}$ For Rousseau, social contract emerges as a strategy to curb social inequalities that were made possible by private property ownership. To disentangle oneself out of this contract, human beings will need to enter into a social pact in a form of agreement with the aim of coming together to form a collective body called the sovereign (Rousseau 1987, 59). The sovereign is formed when free and equal persons come together and agree to create for themselves anew a single body directed towards mutual self-preservation.

Unlike scholars such as Hobbes, Locke and Rousseau who have deployed the social contract theory as a pact between society and the state, some moral philosophers, such as Norman E. Bowie and Thomas Donaldson, have deployed the social contract theory as a framework for conceptualising the moral status and the source of moral obligation of corporations. That is, these scholars view social contract as the justification or foundation of corporate social responsibility towards the environment where corporations operate. Their assumption is hinged on the grounds that corporations now possess an obligation towards a wide spectrum of individuals and environmental entities than previously conceived. This view breaks away from the narrow conception of corporation's responsibility held by scholars such as Milton Friedman, who argues that a corporation's mandate is to exercise social responsibility towards its stockholders and the shareholders only without recourse to other elements in the society where the corporation operates. Friedman canvassed for the adoption of a narrow conception of corporate responsibility rather than a broader conception noting that the latter is incompatible with the economic practices of a free society. He argues further that any attempt to exercise social responsibility will be at the expense of shareholders' profit and inimical to the acceptable protocols of how businesses should operate. For him, engaging in any social intervention commitment as corporations do these days does not only neglect a corporation's obligation towards its stock and shareholders but also serves as a surreptitious usurping of government responsibilities towards its citizens (Friedman 1981). In contrast to this view, scholars such as Christopher D. Stone have argued for a broad conception of corporations' responsibility towards the community in which these corporations are located. Stone defends the broad view of corporation's responsibility and argues inter alia that legal instruments are not sufficient to ensure that corporations act in a socially appropriate or desirable manner: some other requirements need to be satisfied to promote social responsibility of corporations. In keeping with the tenents of the broad conception of corporation's moral obligation to the society, Bowie and Donaldson have argued that a further requirement of ensuring that corporations conduct themselves in a socially responsible way will be to unravel the moral foundations of corporations' obligations to the society. Their strategy hinges on the assumption that the social contract theory underpins corporate social responsibility protocols, and this to them provides a justification for why corporations need to satisfy their social obligation towards the society.

For instance, Bowie avers that one of the ways by which we can assess the moral status of corporations is to rely on the contractual agreement upon which the corporation was first

\footnotetext{
${ }^{4}$ To Locke, the state of nature is not brutish because it allows individuals the liberty to conduct their lives as they deem fit. To him, though the state of nature is pre-political, it is not pre-moral because there exist moral codes to be obeyed. Hence, the law of nature itself imposes on us some moral principles emanating from God with regards to our lives, health, liberty and possessions (See Locke 2003, para 6). However, the state of nature could degenerate into a state of war over property dispute where individuals could invade others and appropriate their property. Therefore, to curb such a mayhem from emerging, there is the need to abandon the state of nature by coming under contract to establish a civil authority that will serve a communal interest and promote mutual selfpreservation.
} 
established. He provides an account as to how contractual moral obligation of a corporation is founded, and here is the crux of his thought. At the inception of any business, stockholders or corporation owners enter into a social pact with the society and the society, in turn, places certain obligations and duties on the corporation in return for the permission to do business. It is this commitment to uphold the content of the pact that binds corporations towards satisfying their part of the contract in a form of exercising their social obligations towards the society. Bowie captures this in the following remarks:

In many discussions of business ethics, no one defines terms like "moral" or "corporate responsibility." This inadequacy can be corrected by adopting the perspective of the contract analysis. The morality of business or corporate responsibility is determined by the terms of the contract with society. The corporation has those obligations which the society imposes on it in its charter of incorporation. In accepting its charter, the corporation accepts those moral constraints (Bowie 1992, 448).

On his part, Donaldson provides a robust analysis of corporate moral obligation by examining whether corporations or profit-making businesses should be held morally responsible for their activities. Donaldson surveys an array of core issues concerning a corporation's moral obligation and the problems that emerge in an attempt to define the moral status of corporations. We shall focus on two main issues: Donaldson argument for defining the status of corporations as moral agents and his contractarian view about corporations' moral obligation.

Like Bowie, the crux of Donaldson's view is that a corporation's moral obligation is constructed upon a social contract that establishes it. His initial attempt was to answer the following question: what is a moral agent and what is it that makes corporations moral agents? In answering these questions, Donaldson argues that in spite of the fact that corporations are regarded as legal persons, they cannot actually be regarded as persons in a moral sense. In spite of the fact that Donaldson is not willing to allow that corporations are moral persons; he opines that corporations can be regarded as moral agents. He thus set out the criteria for determining the moral agency of corporations: "the capacity to use moral reasoning in decision making, and (2) the capacity of the decision-making process to control not only overt corporate acts but also the structure of policies and rules" (Donaldson 1982, 30).

Condition 1 is very crucial in lifting corporations above the levels of machines. That is, Donaldson claims, to be a moral agent, one needs to have reasons for what one does and some of these reasons must be moral. He avers that though corporations are unable to think like human beings, they take decisions and use reasons to justify some of these decisions. On this showing, corporations can be said to be "morally accountable" (Donaldson 1982, 30). Condition 2 is crucial in maintaining a corporation's moral activities. According to Donaldson, "for a corporation to be a moral agent, not only must it be able to use moral reasons in its decision-making, but it must be capable of controlling the structure of its policies and rules" (Donaldson, 198230). His argument is that cooperate moral agency also implies the responsibility of maintaining corporate moral faculties such as policies, rules and procedures.

Having argued that corporations are moral agents, Donaldson went further to justify the existence of corporations by offering a contractarian analysis that reveals why corporations should exercise a moral obligation towards society. He does so by discovering the justification of corporations' existence which he deploys as a further justification for a corporation's moral obligation to the society.

Donaldson argues that a corporation's right to exist usually couched in terms of a corporation's freedom to choose to incorporate does not exhaust all the options as to why corporations ought to exist. In fact, as he rightly points out, the right to drink every night does not provide the 
justification why one ought to be drunk every night (Donaldson 1982, 38-39). Analogously, the right to establish a corporation does not necessarily explain why one ought to establish a corporation. Something other than legal right should justify why any group of persons might want to establish a corporation. The missing link here is the contractual agreement: it is that which justifies corporations' existence and further justifies their moral obligation towards society. Donaldson explains that the contract that legitimizes the operation of corporations is usually between a productive organisation and the individual members of the society, not between a corporation and some supra-individual, social entity. ${ }^{5}$

According to Donaldson, the conditions of the contractual agreement are given schematically as follows: "We (the members of society) agree to do X, and you (the productive organizations) agree to do Y." ... [which] means that the task of a social contract argument is to specify X where $\mathrm{X}$ refers to the obligations of society to productive organisation and to specify $\mathrm{Y}$, where Y refers to the obligations of productive organizations to society" (Donaldson 1982, 43). This condition, according to Donaldson, legitimizes corporations' existence and their moral obligation to society. Donaldson's view about a corporation's moral obligation as emerging from social contract is captured in the following remarks:

Why should corporations exist at all? What is the fundamental justification for their activities? How can we measure their performance, to say when they have performed poorly or well? A social contract helps to answer these questions. Corporations considered as productive organizations exist to enhance the welfare of society through the satisfaction of consumer and worker interests, in a way which relies on exploiting corporations' special advantages and minimizing disadvantages. This is the moral foundation of the corporation when considered as a productive organization (my emphasis) (Donaldson 1982, 54).

In spite of the fact that there are some nuances between Bowie's and Donaldson's analyses of a corporation's moral obligation to the society, a common thread runs through their positions. Their idea is that before businesses are established, stockholders and shareholders enter into a social pact or a contractual agreement with the society. The conditions indicated in the contractual agreement provide the legitimacy for these corporations to run and thus places certain social requirements upon the corporations to fulfill. These social requirements are said to generate a moral constraint upon the corporation to act morally. So, whatever a "corporation's moral obligations are contained in the contract itself." (Bowie 19924, 48). Let us assume that $\mathrm{X}$ is the contractual agreement, forming the substructure, and $\mathrm{Y}$ is the corporations' moral obligation, forming the superstructure; according to the contractual moralists, there is a logically necessary relationship between $\mathrm{X}$ and $\mathrm{Y}$ such that wherever $\mathrm{X}$ occurs $\mathrm{Y}$ is bound to follow. This means that whenever a corporation enters into a contractual agreement with society, such contractual agreement places on the corporation a moral obligation towards society. Hence, it is the contractual agreement that explains why corporations ought to be moral.

\footnotetext{
${ }^{5} \mathrm{He}$ defines society as an aggregate individual who makes up societies or to something over and above the sum of those individuals) (Donaldson 1982, 42).
} 


\section{CONTRACTUAL AGREEMENT AND CORPORATIONS' MORAL OBLIGATION}

In several respects, the idea that moral obligation emerges for corporations from a social contract falls short of answering the question about why corporations need to be moral. The problem is that morality does not always emerge from social contract. That is to say, a corporation's moral obligation is not always justified upon a social pact that it has entered into with society. This is because there is no logically necessary relationship between contractual agreement establishing the legitimacy of a corporation and the corporation's moral obligation. Let us take, for example, a corporation's attempt to build schools, provide recreational facilities and employ local people to improve local contents and provide employment as the conditions specified in the contract that justify its existence and its moral obligation towards society. Building schools, recreational centres and so on, for instance, are social demands that do not necessarily translate into moral responsibility. It is not convincing to regard all societal demands of corporations as moral demands because this has the logical implication that corporations act immorally if they fail to live up to the social demands upon which their contract with the society was established. Indeed, a society may make more social demands that may not include moral demands. ${ }^{6}$ In those cases, such agreements do not yield moral constraints on corporations. Unless contractual moralists are able to clarify the distinction between "what is morally required and what is socially required, discussions of corporate morality become confused" (De George 1984,551). When we slide from social obligation to moral responsibility, the resulting confusion blurs our understanding of where a corporation's moral obligation actually emanates.

Contrary to the above claim, an objector may demur that social contract places moral obligations on corporations. She may argue that what is regarded or termed as moral obligation here is not necessarily the social requirements that the society expects corporations to fulfill. Rather, it is certain constraints on the contractual agreement itself that imposes moral obligation with regards to corporations' conduct. Like Bowie argues:

In addition to the obligation spelled out in the contract itself, there are certain requirements, moral background conditions, if you will, which are assumed. Certain moral rules are rules that are required if contracts are to be made at all. These moral requirements are as obligatory as the obligations spelled in the contract itself (my emphasis) (Bowie 1992,448).

These moral constraints referred to in the preceding passage, though ingrained on the contract, are not necessarily documented as part of it. When contractual agreements are signed, certain moral constraints accompany them and some of these moral constraints are implied. For instance, parties in the agreement are expected not to break their promise with regards to upholding the conditions that were agreed upon in the contract. Or parties in the contract are expected to remain loyal to the conditions specified in the contractual agreement. The idea is, the contractual moralists might argue as seen in Bowie's remarks above, that these moral constraints do not constitute a set of formally specified obligations but a set of binding and abstract moral principles. Thus, promise-keeping and fidelity, though not necessarily

\footnotetext{
${ }^{6}$ A little caution is required here so that we are not construed as saying that the societal demands included in a social contract are not morally binding on corporations, and that corporations are free to fail to fulfil them. Let us suppose that one of the social demands imposed by a corporation by society in the charter that establishes the corporation is that it requires arms to destabilize a neighbouring community. Such a demand will qualify as a societal demand but wouldn't pass for a moral demand even if the corporation keeps the promise and fulfils.
} 
documented as part of the contract are implicit in the contract and they constitute the moral constraints that accompany contractual agreements between society and corporations, and this explains why corporations should exercise moral obligation to society. In other words, it is the contractual relationship between the corporations and the society that explains why corporations should be moral not the social intervention programmes corporations embarked on, per se. It is this that provides the theoretical basis for justifying the moral underpinnings of corporations' moral obligations.

For example, if a corporation which agreed, as part of the charter that establishes it, to build a school for the society in which it is located fails to fulfill this social requirement, one might say that the corporation has acted immorally on the basis that it failed to fulfill the moral principles of promise-keeping or fidelity, implicitly contained in the contract. So, we might say the reason why the corporation acted immorally is that it broke its promise established in the contractual agreement - that it will build a school for the community. Defenders of contractual morality might argue on the basis of this analysis that the act of satisfying a social requirement in itself is not necessarily moral; it is the commitment or otherwise to fulfill these implicit requirements that yields morality. In other words, it is the violation or fulfillment of these implicit requirements that raises moral concerns on the part of the corporation. ${ }^{7}$

As much as we might want to agree that promise-keeping underlies the morality of contractual agreement, it is doubtful that every promise emerging from a contractual agreement places a moral obligation on the "promiser. In other words, as much as one may agree that moral obligations (implicit requirements of the contract such as promise-keeping and fidelity) could emerge from a social contract, it remains doubtful if social contract alone is sufficient to compel corporations to act morally. Let us take for instance the act of promise-keeping and fidelity, it is possible for some moral agent to keep a promise or remain loyal to a contractual agreement for bad or immoral reasons. A gang of criminals, for example, may agree to murder innocent persons, traffic drugs and engage in palpable deceptions while remaining loyal to the dictates of the contract. In a similar vein, a culture may agree to treat members of other cultures as inferior and remain loyal to the agreement, or perpetually keep the promise to uphold the tenets of the agreement. On this construal, though they are abiding by the moral constraints implied in the contractual agreement, their actions are immoral. Suppose again, for instance, that a corporation enters into a contractual agreement with a society that has the potential to deplete the environment of local communities or destroy water bodies and other sources of water outlets in the community. Suppose also that the parties to the contractual agreement intentionally neglect these potential hazards and proceed to uphold this contract; what moral obligation is imposed on the corporation on this occasion? The problem with the idea that contractual agreement compels corporations to act morally remains a suspect because we cannot be sure that ipso facto any contractual agreement will necessarily impose a moral constraint on corporations.

The examples we have offered to elucidate our claim that contractual agreement may not yield moral obligation on corporation so far may sound a bit strong and controversial. The reason is that in the law of contracts, a contract will not be enforced if its enforcement is contrary to public policy. ${ }^{8}$ But such a condition needs not derail the claim being advanced in this essay on the grounds that legal instruments or legislation themselves frequently fail to consider one's

\footnotetext{
7 This view resonates with Charles Fried's claim that promises provide the moral foundation of the law of contract. For scholars like Fried, contracts involve a purely individual morality of promise-keeping which are values in themselves because it promotes autonomy (Fried 1981).

${ }^{8}$ See the Restatement (Second) of Contracts, Section 178) and Richard Kraut (1984, chap. 2).
} 
moral obligation towards another person or the state: where actions that are legally justified fail to be morally justified such as in the case where a court rules that an individual is legally justified to acquire a state assert but morally unjustified to do so. ${ }^{9}$ Sometimes, the state may be morally unjustified in their legislation such as in Socrates' trial in the Crito. We do not intend to get embroiled in the debate about the relationship between the law and morality, but a useful implication can be drawn from the concerns raised above that a state can preside on the jurisdiction of a contract whose content may be morally unjustifiable and this may have the potential to inflict an abuse on the moral obligation that may flow from such a contract. So, our examples above citing issues like 'stealing', 'murder' and 'wanton abuse of the environment' are not entirely out of place if such practices may occasionally feature in contracts that have legal force.

Having noted this, one might be right to argue that some contractual agreement may fail to impose moral obligation even if such contractual obligation yields the act of promise-keeping. ${ }^{10}$ A less controversial example will be necessary to drum home our point. Let us assume that as part of its charter that establishes it, a corporation is required to recruit indigenous people to promote employment in the host community. Since this is a societal demand, the corporation is morally obliged to fulfil it once it accepts the charter to incorporate. Meanwhile, let us suppose that most people of the host communities are illiterate or are not educated enough to assume high level portfolios in the company. The corporation upon receiving several applications from the locals now became aware that several of the applicants were not suitable for the job because they fell below the required qualification level. Employing people below the required qualification mark (even if they are capable of executing their mandate as employees) is a violation of the code of ethics of the corporation. But here is the case, the corporation has already agreed and imposed the obligation upon itself to recruit local people as part of the charter that establishes it. Hence, it cannot opt out of the promise that it has obligated itself to undertake. If the corporation decides to break the promise, it would be a violation of its moral obligation to the society. On the other hand, if it proceeds to keep the promise it will be a moral wrong since it is a violation of corporate code of ethics. How does this confusion get resolved?

Our claim is that it is wrong for an agent to promise what it would be wrong for him/her/it to accomplish. On this occasion, though the contract is accompanied with a promise, the promise fails to carry moral weight since it will fail to produce an act that is moral if the company decides to fulfil it. The corollary of our claim is that if honouring of a promise is conventionally considered as an example of a moral obligation that accrues from a contractual agreement, then when a promise fails to accompany a moral obligation, the contract automatically fails to yield morality. Unless one wants to assume that we could have the moral obligation to do the immoral, we don't see how possessing a moral obligation to commit an immoral act could create an act that is morally salient.

Thus far, we have argued that contractual agreement between corporations and society does not necessarily impose moral constraints on the former. It is important to note that our argument is not meant to deny that contractual agreement plays a role in corporations moral obligation effort, rather we argue that corporation's moral responsibility does not necessarily arise from a contractual agreement. And this has serious implication on the way we conceptualize corporation's moral obligation. That is, once the necessary link between the contractual agreement and corporation's moral obligation is denied, it becomes logically absurd to say that

\footnotetext{
${ }^{9}$ Ablakwa and Another v Attorney General and Another (Ruling) (J7/5/2012) [2013] GHASC 143 (23 January 2013). Retrived from: https://ghalii.org/gh/judgment/supreme-court/2013/143

10 We are using promise-keeping as paradigm moral obligation.
} 
corporation's moral obligation is justified on a social contract. In other words, it will mean that the emanation of corporations' moral obligation from a social contract is subject to chance or accidentality and this betrays the assumption that a corporation's moral obligation should be sought from a contractual agreement that establishes it, or that a corporation ought to be moral on the basis of a social contract.

The assumption that a corporation moral obligation emerges from a social contract can be avoided if one were to argue that contractual agreement sustains corporations' moral obligation rather than causes it. That is to say, it will be much compelling to assume that the reason why a corporation will act morally is not that moral obligation is imposed on it by, or emerges from, contractual agreement but because moral obligation is sustained by the contractual agreement on the corporations. Our strategy rests on the premise that it is the inclination ${ }^{11}$ to regulate corporations' morality that propels corporations to enter into a social pact with the society so that the contractual agreement becomes an "ombudsman" of a sort to regulate the excesses of the interest maximization inclination of the stockholders and shareholders of corporations.

Let us remind ourselves of the narrow conception of a cooperation's moral obligation where corporations exercise moral obligation towards only their stock and shareholders. Here, the cooperation's responsibility is to increase profit for their owners and not to respond to any societal demands, whether moral or social (Milton Friedman, 1970). At this level, it may be said that corporations have the inclination to maximize utility for the benefit of their owners. In other words, corporations have a rational self-interest to promote only the wellbeing of their owners. But critical insight from game theory suggests the contrary. It is a common knowledge that two individuals acting in their own self-interest does not yield an optimized reward for each of them.

Let us deploy the prisoner's dilemma paradox to shed some light on this point. Suppose two prisoners who have been accused of a crime are both quarantined in different locations in order to make collusion or an attempt to cooperate difficult for them, and their chances of being freed or imprisoned depend on the following. If one confesses and the other does not, the one who confesses will be released immediately and the other will spend 20 years in jail. If neither of them confesses, each will be held up in prison for a few months. If each confesses, both will be put in jail for 15 years. Since both cannot communicate with each other, it is in their own selfinterest to confess and protect themselves at the expense of each other which inevitably will land them in a worse state than if they had cooperated with each other by remaining silent (Gauthier 1986, 80).

The lesson drawn from the above paradox is that there is no reward when individuals act in their own self-interest: when people act in their self-interest, they hope to avoid falling over, but it eventually results in disastrous outcomes. In an analogous manner, the paradox provides a cue for owners of corporations not to act in a self-interested manner since it could generate disastrous end. So, one might argue that the driving force behind corporations entering into a

\footnotetext{
11 The argument that corporations have inclination to be moral have long ago been espoused by some scholars. For instance, French argues that corporations are subjects of moral obligation from pressure from the society and therefore are intentional actors and since corporations have internal decision-making structures then they have the inclination to take moral decisions as a collective. See French (1984). Goodpaster and Mathew in a widely respected article also argued that conscience can reside in corporations since corporations evince both rationality and respect in their goal-setting and decision-making capacities. See Goodpaster and Mathew (1982). Goodpaster later develops this view further in his 1983 article.
} 
pact with the society is to maximize their advantage and minimize their loss. But more importantly, it is to place a moral constraint on the rational choice of corporations because the cost of being immoral (Here, we are taking self-interestedness as an immoral act) will burden the advantages. Like Plato who argues that the cost of being immoral cannot compensate for the disharmony of the soul, the same applies to corporations by parity reason ${ }^{12}-$ the maximization of self-interest cannot compensate for the debt of being immoral. Hence, by entering into a social pact with society, rational self-interest recommends the abandonment of self-interest rationality in favour of moral reasoning. After all, when there is no danger of reprisal, there is no cause for being moral. ${ }^{13}$

One may, on the basis of the preceding paragraph, argue that before entering into a contractual agreement with the society, corporations already had a moral propensity to truncate their rational self-interest in favour of the good of the society. And the inclination to abandon one's rational self-interest by entering into a social pact meant to constrain this self-interest is in itself an act of being moral (barring all the optimal incentive that is likely to emerge from such a contract). On this showing, it can be said that corporations are indeed moral before entering into any social pact that places a moral obligation on them. This is why we say that a contract sustains rather than creates the moral obligation of corporations to host communities. Therefore, the answer to the question "why a corporation should be moral?" lies in the answer to the question "why corporations should enter into a social pact with the society?" And the answer is that corporations are moral because they have the capacity to constrain themselves by entering into a social pact that will sustain that constraint. Hence, when a corporation enters into a contractual agreement with the society, it does so not because it wants to assume a fresh moral status; it does so because it wants to keep a check on its moral obligation to the society.

Redefining the issue this way appears much more compelling because on the extant model, when a contractual agreement fails to produce a moral obligation upon a corporation, the contractual moralists' analysis of corporation's social responsibility initiatives may fail to be justified on a social contract. This takes us back to where we started from: the old question about why corporations should be moral stares us once again in the face. In order to avoid this unpalatable conclusion, one may argue that where contractual agreement fails to take into account corporation's moral obligation, we can nevertheless explain the basis of corporation's moral obligation by tracing it to the corporation's motivation or drive to enter into a contractual agreement with society. In other words, where the contractual agreement fails to impose a moral obligation on corporations, one may explain away this clutter by suggesting that the contractual agreement fails to sustain the corporation's moral obligation.

Our account resonates with Donaldson's claim that corporations are moral agents. However, for us, corporation are moral agents even before entering into the social contract. Recall Donaldson's criteria for moral agency as the capacity to use moral reasoning in decisionmaking, and the capacity to use this decision-making process to regulate corporation's behaviour. Wouldn't one be right on Donaldson's proposal, if she were to argue that the capacity to use moral reasoning already makes one moral? If this is correct then a corporation's moral obligation to the society is contingent upon its moral agency not on a contractual agreement. But Donaldson does not say exactly this. He rejects the moral agency of corporation

\footnotetext{
12 See Plato's Republic, 444b-445b and 589e -90a, (pp. 108 \& 236).

${ }^{13}$ This rides on a similar idea expressed by Glaucon in the Republic. Suppose, one were to possess the ring of Gyges - a ring that makes the wearer invisible and guarantees impunity. Would one have any commitment or the honour to respect other people's belongings? See Plato's Republic, 358ff. In an analogous fashion, would corporations be willing to be moral if there were no reprisal demands from relying on self-interest?
} 
as that which should justify corporation's moral obligation to the society and rather seeks the justification of corporation's moral responsibility on contractual agreement. We depart from Donaldson's position on the basis that once it is established that corporations are moral agents, their moral agency status alone is enough to cause them to be morally responsible - there is no need to go in search for it elsewhere. Corporations' capacity to make moral decision to enter into a social contract is in itself a moral obligation. It is this capacity that culminates in the decision to establish a contract with the society to make themselves morally responsible to society.

Enough has now been said about the fact that corporations are moral agents and that the contractual agreement sustains their moral obligation. A question might then be posed at this juncture: if corporation are moral agents, at what stage do they become moral agents taking cognizance of the fact that upon the extant reading their existence is justified on the charter that establishes them? In other words, for a corporation to operate it requires a special act of legislature granting it a charter to operate and this charter in turn imposes an ultra vires doctrine that confines the corporation to the contract established in the charter. (This has been the argument of Bowie and Donaldson that corporation's contractual agreement with the society is contained in the charter or the articles of incorporation that establishes it). Going by this analysis then, at what point does a corporation become a moral agent prior to the contractual agreement that establishes it? An answer to this question has an implication on our claim that corporations were moral agents before entering into the contract that places moral obligation on them because by the argument of the contractual moralists, before the contractual agreement, corporation do not exist.

This idea that a corporation comes into existence with the charter that establishes it does not logically impede our claim that corporations were moral agents prior to signing the charter if one takes into consideration the structure of modern-day corporations. Bowie and Donaldson were relying on the old conception of corporations and how these corporations come to exist. However, the way corporations are popularly conceived today will not sit pretty well with their view about how corporations come to exist. The earlier chartered corporations, by the argument of Bowie and Donaldson, are instruments of the state and have no independence of their own. This is buttressed by Olufemi Amao's claim that "the earlier chartered corporations, which were completely subject to State control, cannot reasonably be argued to have been a party to the social contract... because of their lack of independence and their unequal status attached to them by virtue of the manner of their creation and the constraint placed on their operation by the State" (Amao 2008, 126). The idea is that the earlier chartered corporations were controlled by the state because state legislative instruments create them, so they have no independence on their own. Indeed, it is a common knowledge that entities who are parties to a contract are expected to be independent, rational and equal participants. So, the issue about a contract that is established from a state-controlled charter is itself a suspect. No contract is legitimate if it is forced or parties are coerced to participate. This issue may raise a number of unpleasant concerns for the contractual moralists but this is not the preoccupation of this essay.

Our contention is that modern day corporation have a different structure from earlier chartered corporations. Unlike earlier chartered corporations, modern corporations have life of their own and are incorporated companies. These new brands of companies are not created by charter: rather they are created through registration and they have autonomous status with important consequences in law. At the level of incorporation, companies are in the process of Corporation, and it is not mandatory that they should register as full-fledged corporations through the articles of incorporation or charter. They retain the right to do so or not. 
Now when we argue that corporations are moral agent before entering into the contract that offers them further legitimacy to operate, we are making reference to incorporated corporations. Our understanding is that the incorporated corporations are moral agents at the level of incorporation within the context of the modern day understanding of the term. And since an incorporated company can determine whether it wants to Corporate (enter into a contract through a charter) or not, it could be said that incorporated corporations have the moral inclination to want to be constrained by a contract that should place a moral obligation on them or not (because they are moral agents and have a moral will). This makes sense when we take into consideration the conditions of establishing a contract: (1) free and informed consent, (2) a quid pro quo, and (3) the rational self-interest of the contracting parties. So, modern incorporated companies have a free and informed consent for entering into a contract (they are not coerced because they are treated as moral agents who can take independent decision), they go into the contract on the basis of quid pro quo (in exchange for something), and have rational interest to maximize profit. (This is akin to Locke's view of social contract, according to which parties to the contract are already moral agents coming to establish a contract for mutual benefit). The idea being expressed here is that incorporated entities enter into the contract to become chartered corporations as free agents with an informed consent. So, they enter into the contract freely as third entrants at a later stage between the society and the state and thus impose upon themselves a sort of moral constraint arising from the contract to sustain and check their rational self-interest propensities. ${ }^{14}$

This is consistent with our claim that legal obligation does not necessarily carry moral obligation because by the preceding analysis, the contractual agreement does not impose moral obligation on the corporation. It again goes further to affirm our claim that corporations are actually moral agents before entering into the social contract. It is this moral agency that forms the basis of corporations' entrance into the contract. So, a corporation's social contract with the society does not necessarily place a moral obligation on it and there is therefore no need to justify a corporation's moral obligation on a social contract. But as we noted earlier on, in spite of the setback, contractual agreements are useful in sustaining or regulating a corporation's moral obligation to the society.

\section{Conclusion}

The idea that a corporation's moral obligation emerges from a social contract as seen in this essay invites several queries. A more conspicuous query presented in this essay is the idea that a social contract does not necessarily impose a moral obligation on corporations since such a contractual agreement may not yield a moral obligation at all. One implication of such a view is that even a gang of thieves can enter into a contract to rob people of their property while remaining loyal and fair to the members of the gang in terms of the distribution of incentives from their robbery escapades. We have argued that such a view assumes that one can have a moral obligation to carry out a moral wrong. Our contention is that such cases where contracts imposes moral obligation on parties to commit a moral wrong, fly in the face of morality. On this showing, we have argued that corporation's moral obligation does not necessarily emerge from a social contract owing to the fact that there are chances that contractual agreement may not succeed in placing a moral obligation on corporations. We resolve this theoretical confusion

\footnotetext{
14 Here rationality is defined as a "constrained utility maximization" (Jody S. Kraus and Jules L. Coleman 1987, 715).
} 
by suggesting that a corporation's moral obligation should be said to be "sustained" by but not "produced" by a contractual agreement. Our inspiration is drawn from modern day incorporated corporation and how they become chartered corporations.

\section{References}

Amao, Olufemi. 2008. "Corporate Social Responsibility, Social Contract, Corporate Personhood and Human Rights Law: Understanding the Emerging Responsibilities of Modern Corporations". Australian Journal of Legal Philosophy. 33: 126

Bowie, Norman. E. 1992. "Changing the Rules". In Applying Ethics, edited by Jeffrey Olen and Vincent Barry London: Wadsworth Publishing Company.

Charles, Fried 1981. Contract as Promise: A Theory of Contractual Obligation. Oxford: Oxford University Press.

De George, Richard. 1984. “Corporations and Morality”, edited by Thomas Donaldson. Nous, 18(3): 548-551.

Donaldson, Thomas. 1982. Corporations and Morality. Eaglewood Cliffs: NY: Prentice Hall Inc.

French, Peter. 1984. Collective and Corporate Responsibility. New York: Columbia University Press.

Friedman, Milton. 1981. Capitalism and Freedom. Chicago: Chicago University Press

Gauthier, David. 1986. Moral by Agreement. Oxford NY: Oxford University Press.

Goodpaster, Kenneth. 1983. 'The Concept of Corporate Responsibility”. Journal of Business Ethics. 2(1):1-22.

Goodpaster, Kenneth and Mathews, John. 1982. “Can a Corporation have Conscience?" Harvard Business Review, 132(60):132-140.

Hobbes, Thomas. 1651. The Leviathan: Reprint of 1651. Smith George (Ed.), Translated by F. L. Pogson, Chicago: University of Chicago Press

Kraus, Jody and Coleman, Jules. 1987. “Morality and the Theory of Rational Choice”. Ethics, 97(4):715-749.

Kraut, Richard. 1984. Socrates and the State. Princeton: Princeton University Press.

Locke, John 2003. Two Treaties of Government and a Letter Concerning Toleration. Yale: Yale University Press.

Plato 1974. Republic. Translated by G.M.A. Grube. Indianapolis, In: Hackett.

Plato 1981. Crito. In G.M.A. Grube (Trans), Five Dialogues (pp. 45-58). Indianapolis: Hackett Publishing Company.

Rousseau, Jean-Jacques. 1987. The Basic Political Writings. (Trans. Donald A. Cress) Hackett Publishing Company. 